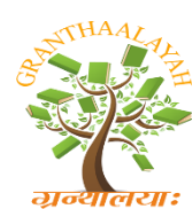

$$
\begin{aligned}
& \text { INTERNATIONAL JOURNAL OF RESEARCH - } \\
& \text { GRANTHAALAYAH } \\
& \text { A knowledge Repository }
\end{aligned}
$$

Management

\title{
A NOVEL TOURISM COMPETITIVENESS RANK
}

\author{
Hegazy Zaher ${ }^{1}$, Ahmed Hafez ${ }^{* 2}$ \\ ${ }^{1}$ Prof. of Mathematical Statistics, Statistical Department, Institute of Statistical Studies and \\ research (ISSR), Cairo University, Giza, Egypt \\ ${ }^{* 2}$ Researcher, Operations Research Department, Institute of Statistical Studies and Research \\ (ISSR), Cairo University, Giza, Egypt
}

DOI: https://doi.org/10.29121/granthaalayah.v5.i5.2017.1848

\begin{abstract}
This paper proposes a novel tourism rank to arrange countries in tourism. The proposed rank is based on fifteen factors, the fourteen factors affecting the tourism rank considered in the Travel $\&$ Tourism competitiveness reports and the number of tourist arrivals considered in United Nations World Tourism Organization rank. The proposed method gives significant differences compared to the traditional ranks used by the Travel \& Tourism competitiveness reports and United Nations World Tourism Organization rank.

Keywords: Travel and Tourism Competitiveness; Tourism Country Rank; Proposed Rank; United Nations World Tourism Organization (UNWTO).

Cite This Article: Hegazy Zaher, and Ahmed Hafez. (2017). "A NOVEL TOURISM COMPETITIVENESS RANK.” International Journal of Research - Granthaalayah, 5(5), 164-169. https://doi.org/10.29121/granthaalayah.v5.i5.2017.1848.
\end{abstract}

\section{Introduction}

Tourism is an important factor to the economy of all countries. The Tourism rank of any country reflects its attractiveness to tourist arrivals. There are two well-known tourism ranks, the first one of The United Nations World Tourism Organization and is based on the number of tourist arrivals, the other due to Travel \& Tourism competitiveness report and is based on 14 factors listed in International Travel and Tourism reports [1] and these factors divided into 3 main groups as follows:

Group 1

Travel \& Tourism regulatory framework and includes 5 factors

1) Policy rules and regulations.

2) Environmental sustainability.

3) Safety and security. 
4) Health and hygiene.

5) Prioritization of Travel \& Tourism.

Group 2

Travel \& Tourism business environment and infrastructure and includes 5 factors

6) Air transport infrastructure.

7) Ground transport infrastructure.

8) Tourism infrastructure.

9) ICT infrastructure.

10) Price competitiveness in the T\&T industry.

Group 3

Travel \& Tourism human, cultural, and natural resources and includes 4 factors

11) Human resources.

12) Affinity for Travel \& Tourism.

13) Natural resources.

14) Cultural resources.

The UNWTO tourism rank is the ranking of countries according to the number of tourist arrivals (the country with the highest number of tourist arrivals has rank 1 and so on). Table (1) shows the number of tourist arrivals and the country rank during (2008 - 2013) in United Nationals World Tourism Organization.

Table 1: Country rank of United Nations World Tourism Organization (UNWTO)

\begin{tabular}{|c|c|c|c|c|c|c|c|c|}
\hline \multirow[b]{2}{*}{ Country } & \multicolumn{2}{|l|}{2008} & \multicolumn{2}{|l|}{2009} & \multicolumn{2}{|l|}{2011} & \multicolumn{2}{|l|}{2013} \\
\hline & $\begin{array}{c}\text { International } \\
\text { Tourist } \\
\text { arrivals } \\
\text { (million) }\end{array}$ & Rank & $\begin{array}{c}\text { International } \\
\text { Tourist } \\
\text { arrivals } \\
\text { (million) }\end{array}$ & Rank & $\begin{array}{c}\text { International } \\
\text { Tourist } \\
\text { arrivals } \\
\text { (million) }\end{array}$ & Rank & $\begin{array}{c}\text { International } \\
\text { Tourist } \\
\text { arrivals } \\
\text { (million) }\end{array}$ & Rank \\
\hline France & 79.2 & 1 & 76.8 & 1 & 81.6 & 1 & 83.6 & 1 \\
\hline $\begin{array}{l}\text { United } \\
\text { States }\end{array}$ & 57.9 & 2 & 55.0 & 2 & 62.7 & 2 & 70.0 & 2 \\
\hline Spain & 57.2 & 3 & 52.2 & 3 & 56.2 & 4 & 60.7 & 3 \\
\hline China & 53.0 & 4 & 50.9 & 4 & 57.6 & 3 & 55.7 & 4 \\
\hline Italy & 42.7 & 5 & 43.2 & 5 & 46.1 & 5 & 47.7 & 5 \\
\hline $\begin{array}{l}\text { United } \\
\text { Kingdom }\end{array}$ & 30.1 & 6 & 28.2 & 6 & 29.3 & 7 & 31.1 & 8 \\
\hline Turkey & 25.0 & 7 & 25.5 & 7 & 34.7 & 6 & 37.8 & 6 \\
\hline Germany & 24.9 & 8 & 24.2 & 8 & 28.4 & 8 & 31.5 & 7 \\
\hline Malaysia & 22.1 & 10 & 23.6 & 9 & 24.7 & 9 & Out & Out \\
\hline Mexico & 22.6 & 9 & 21.5 & 10 & Out & Out & 24.2 & 10 \\
\hline $\begin{array}{l}\text { Russian } \\
\text { Federation }\end{array}$ & Out & Out & Out & Out & 22.7 & 10 & 28.4 & 9 \\
\hline
\end{tabular}

Source: United Nationals World Tourism Organization (UNWTO), UNWTO Tourism Highlights 2010, 2011, 2013 and2015 Editions [5], [6], [7] and [8]. 
Another international ranking is given by Travel \& Tourism Competitiveness report. Each country has a score calculated as given in the Travel \& Tourism Competitiveness report. The country with the highest score has rank 1 and so on. Table (2) shows the score and country rank in the travel \& tourism competitiveness reports. The mentioned ranks are not the same.

Table 2: Score and country rank in the Travel \& Tourism Competitiveness reports

\begin{tabular}{|l|l|l|l|l|l|l|l|l|}
\hline \multirow{2}{*}{ Country } & $\mathbf{2 0 0 8}$ & $\mathbf{2 0 0 9}$ & $\mathbf{2 0 1 1}$ & $\mathbf{2 0 1 3}$ \\
\cline { 2 - 9 } & Rank & Score & Rank & Score & Rank & Score & Rank & Score \\
\hline Switzerland & 1 & 5.63 & 1 & 5.68 & 1 & 5.68 & 1 & 5.66 \\
\hline Germany & 2 & 5.41 & 2 & 5.41 & 2 & 5.50 & 2 & 5.39 \\
\hline Spain & 3 & 5.30 & 4 & 5.29 & 6 & 5.29 & 3 & 5.38 \\
\hline $\begin{array}{l}\text { United } \\
\text { Kingdom }\end{array}$ & 4 & 5.28 & 6 & 5.22 & 5 & 5.30 & 4 & 5.38 \\
\hline United States & 5 & 5.28 & 5 & 5.28 & 4 & 5.30 & 5 & 5.32 \\
\hline France & 6 & 5.23 & 3 & 5.34 & 3 & 5.41 & 6 & 5.31 \\
\hline Italy & 7 & 4.84 & 7 & 4.78 & 7 & 4.87 & 7 & 4.90 \\
\hline Malaysia & 8 & 4.63 & 8 & 4.71 & 8 & 4.59 & 8 & 4.70 \\
\hline Turkey & 9 & 4.19 & 11 & 4.20 & 11 & 4.37 & 11 & 4.44 \\
\hline Mexico & 10 & 4.18 & 10 & 4.29 & 10 & 4.43 & 9 & 4.46 \\
\hline China & 11 & 4.06 & 9 & 4.33 & 9 & 4.47 & 10 & 4.45 \\
\hline $\begin{array}{l}\text { Russian } \\
\text { Federation }\end{array}$ & 12 & 4.04 & 12 & 4.14 & 12 & 4.23 & 12 & 4.16 \\
\hline Egypt & 13 & 3.96 & 13 & 4.09 & 13 & 3.96 & 14 & 3.88 \\
\hline Ukraine & 14 & 3.76 & 14 & 3.84 & 14 & 3.83 & 13 & 3.98 \\
\hline
\end{tabular}

Source: The Travel and Tourism competitiveness report 2008, 2009, 2011 and 2013 reports [1], [2], [3] and [4].

\section{The Proposed Rank}

The proposed rank is based on 15 factors, the number of tourist arrivals in addition to the 14 factors considered in the Travel \& the Tourism competitiveness report. The proposed rank can be calculated for any year using the following steps:.

1-For a given country, $i$ and factor $j$, calculate the standard value of factor $j$ (a value in the interval $[1,2]) T_{i}(j)$ of the factor $j$, where

$$
T_{i}(j)=\frac{\text { existing score }(j)-\min (j)}{\operatorname{Max}(j)-\min (j)} \quad+1 \quad, j=1,2, \ldots, 15
$$

Where;

$\operatorname{Max}(j)$ and $\operatorname{Min}(j)$ are the maximum and minimum score of the factor $j$ for the given country(i) in $T \& T$ competitiveness reports.

2- For any country $i, i=1,2, \ldots, 14$ Find the country score $T_{i}$ total $(i)$, where

$\mathrm{T}_{\mathrm{i} \text { total }}(\mathrm{i})=\left[\prod_{\mathrm{i}=1}^{15} \mathrm{~T}_{\mathrm{i}}(\mathrm{j})\right]$

3- Order The $T_{i}$ total, $i=1,2, \ldots, 14$ values from highest to lowest and give the highest value of $T_{i \text { total }}$ the order 1 and so on. 
The following tables give comparisons between the proposed rank and the other ranks in 2008, 2009, 2011, and 2013.

Table 3: Comparison between the proposed rank and other ranks in 2008

\begin{tabular}{|l|l|l|l|}
\hline \multicolumn{1}{|c|}{ Country } & Proposed rank & $\begin{array}{l}\text { Rank in travel and tourism } \\
\text { report }\end{array}$ & Rank in UNWTO \\
\hline Switzerland & Out & 1 & Out \\
\hline Germany & 3 & 2 & 8 \\
\hline United Kingdom & 5 & 4 & 6 \\
\hline France & 1 & 6 & 1 \\
\hline Spain & 2 & 3 & 3 \\
\hline United States & 4 & 5 & 2 \\
\hline Malaysia & 6 & 8 & 10 \\
\hline Italy & 7 & 7 & 5 \\
\hline Turkey & 8 & 9 & 7 \\
\hline Mexico & 9 & 10 & 9 \\
\hline Egypt & Out & 13 & Out \\
\hline China & 10 & 11 & 4 \\
\hline Russian Federation & Out & 12 & Out \\
\hline Ukraine & Out & 14 & Out \\
\hline
\end{tabular}

Table 4: Comparison between proposed rank and other ranks in 2009

\begin{tabular}{|l|l|l|l|}
\hline \multicolumn{1}{|c|}{ Country } & Proposed rank & $\begin{array}{c}\text { Rank in travel \& } \\
\text { tourism report }\end{array}$ & Rank in UNWTO \\
\hline Switzerland & Out & 1 & Out \\
\hline Germany & 3 & 2 & 8 \\
\hline United Kingdom & 5 & 6 & 6 \\
\hline France & 1 & 3 & 1 \\
\hline Spain & 2 & 4 & 3 \\
\hline United States & 4 & 5 & 2 \\
\hline Malaysia & 6 & 8 & 9 \\
\hline Italy & 7 & 7 & 5 \\
\hline Turkey & 9 & 11 & 7 \\
\hline Mexico & 10 & 10 & 10 \\
\hline Egypt & Out & 13 & Out \\
\hline China & 8 & 9 & 4 \\
\hline Russian Federation & Out & 12 & Out \\
\hline Ukraine & Out & 14 & Out \\
\hline
\end{tabular}

Table 5: Comparison between proposed rank and other ranks in 2011

\begin{tabular}{|l|l|l|l|}
\hline \multicolumn{1}{|c|}{ Country } & Proposed rank & \multicolumn{1}{c|}{$\begin{array}{c}\text { Rank in travel \& } \\
\text { tourism report }\end{array}$} & Rank in UNWTO \\
\hline Switzerland & Out & \multicolumn{1}{c|}{1} & Out \\
\hline Germany & 2 & 2 & 8 \\
\hline United Kingdom & 5 & 5 & 7 \\
\hline France & 1 & 3 & 1 \\
\hline
\end{tabular}




\begin{tabular}{|l|l|l|l|}
\hline Spain & 3 & 6 & 4 \\
\hline United States & 4 & 4 & 2 \\
\hline Malaysia & 7 & 8 & 9 \\
\hline Italy & 6 & 7 & 5 \\
\hline Turkey & 9 & 11 & 6 \\
\hline Mexico & Out & 10 & Out \\
\hline Egypt & Out & 13 & Out \\
\hline China & 8 & 9 & 3 \\
\hline Russian Federation & 10 & 12 & 10 \\
\hline Ukraine & Out & 14 & Out \\
\hline
\end{tabular}

Table 6: Comparison between proposed rank and other ranks in 2013

\begin{tabular}{|l|l|l|l|}
\hline Country & $\begin{array}{l}\text { Proposed } \\
\text { rank }\end{array}$ & $\begin{array}{l}\text { Rank in travel \& } \\
\text { tourism report }\end{array}$ & Rank in UNWTO \\
\hline Switzerland & Out & 1 & Out \\
\hline Germany & 5 & 2 & 7 \\
\hline United Kingdom & 3 & 4 & 8 \\
\hline France & 1 & 6 & 1 \\
\hline Spain & 2 & 3 & 3 \\
\hline United States & 4 & 5 & 2 \\
\hline Malaysia & Out & 8 & Out \\
\hline Italy & 6 & 7 & 5 \\
\hline Turkey & 7 & 11 & 6 \\
\hline Mexico & 9 & 9 & 10 \\
\hline Egypt & Out & 14 & Out \\
\hline China & 8 & 10 & 4 \\
\hline Russian Federation & 10 & 12 & 9 \\
\hline Ukraine & Out & 13 & Out \\
\hline
\end{tabular}

\section{Discussion and Conclusion}

1) The proposed rank takes into consideration fifteen factors affecting the tourism in any country and is easily calculated.

2) The given rank is more realistic than the other used methods hence the other two international ranks are special cases of the proposed one.

3) There are a significant difference between the proposed rank and the other two international ranks of United Nations World Tourism Organization and Travel \& Tourism Competitiveness reports.

4) The given idea deserves to be considered by the international tourism organizations.

\section{References}

[1] The Travel \& Tourism Competitiveness Report 2008: Balancing Economic Development and Environmental Sustainability, World Economic Forum.

[2] The Travel \& Tourism Competitiveness Report 2009: Managing in a Time of Turbulence, World Economic Forum. 
[3] The Travel \& Tourism Competitiveness Report 2011: Beyond the Downturn, World Economic Forum.

[4] The Travel \& Tourism Competitiveness Report 2013: Reducing Barriers to Economic Growth and Job Creation, World Economic Forum.

[5] United Nations World Tourism Organization (UNWTO), UNWTO Tourism Highlights 2010 Edition, facts \& figures section at ( www.unwto.org/facts).

[6] United Nations World Tourism Organization (UNWTO), UNWTO Tourism Highlights 2011Edition, facts\& figures section at (www.unwto.org/facts).

[7] United Nations World Tourism Organization (UNWTO), UNWTO Tourism Highlights 2013Edition, facts \& figures section at (mkt.unwto.org).

[8] United Nations World Tourism Organization (UNWTO), UNWTO Tourism Highlights 2015Edition, facts \& figures section at (mkt.unwto.org).

*Corresponding author.

E-mail address: ahmedhafez83@yahoo.com 